\section{Quantification of Enterovirus RNA in Sludge Samples Using Single Tube Real-Time RT-PCR}

BioTechniques 29:88-93 (July 2000)

\begin{abstract}
We have developed a quantitative $R T$ $P C R$ method that can be used to determine the amount of enterovirus RNA in urban sludge samples. This method combines TaqMan $^{\circledR}$ technology with the ABI Prism ${ }^{\mathrm{TM}}$ 7700 real-time sequence detection system. We optimized a one-step RT-PCR that uses a dual-labeled fluorogenic probe to quantify the $5^{\prime}$ noncoding region of enteroviruses. For accurate quantification of the number of copies, a Mahoney type 1 poliovirus RNA standard was designed and produced using genetic engineering. This fragment, quantified using the Ribogreen ${ }^{\circledR}$ method, was used in serial dilutions as an external standard. The method had a 7-log dynamic range (5 to $\left.2 \times 10^{7}\right)$. PCR inhibitors were removed by extracting viral RNA (after virus concentration) using the RNeasy ${ }^{\circledR}$ mini kit with added polyvinylpyrrolidone $(P V P)$ and running the amplification reaction with a mixture containing PVP and T4 gene 32 protein. This real-time quantification of enterovirus RNA allows large numbers of samples to be screened. Its sensitivity, simplicity and reproducibility render it suitable as a screening method with which to characterize enteroviruses, the presence of infectious particles being subsequently confirmed by cell culture.
\end{abstract}

\section{INTRODUCTION}

There are generally two kinds of methods for detecting enteric viruses in environmental samples, depending on whether they are based on cell culture infectivity or on molecular detection methods such as PCR followed by nucleic acid hybridization (16). Compared to time-consuming cell culture assays, PCR is rapid, sensitive and specific. It is also capable of detecting non-cytopathogenic, slow-growing and rare viruses in complex environmental samples such as sewage or sludge (20). Current amplification techniques are either qualitative (10) or quantitative with the measurement of the amount of product amplified as their end point (25).

In this study, we suggest a singletube, one-step, real-time RT-PCR assay for the quantification of enteroviruses in sludge samples using $\operatorname{TaqMan}^{\circledR}$ technology (Roche Molecular Biochemicals, Meylan, France). This technology makes use of the $5^{\prime} \rightarrow 3^{\prime}$ nucleolytic activity of AmpliTaq ${ }^{\circledR}$ DNA polymerase and uses primer pairs in conventional amplification and a duallabeled fluorogenic probe $(5,13)$. Three major difficulties need to be overcome in the development of such a technique: (i) because enteroviruses are RNA viruses, RT-PCR needs to be optimized in a single step to keep manipulation time to a minimum; (ii) because treated sludge contains only small quantities of enterovirus, a highly sensitive technique is required; and (iii) the purest possible genetic material needs to be extracted because sludge samples contain numerous organic compounds (polyphenols and humic acids) and heavy metals that are liable to inhibit amplification enzymes $(7,17,21)$.

The use of polyvinylpyrrolidone (PVP) in genome extraction and the T4 gene 32 protein during amplification enabled us to achieve a complete proto$\mathrm{col}$, from the extraction of virus from sludge to the counting of genome copies. Here, we present the first results obtained with samples of natural and artificially contaminated sludge. We compare these results with measurements made using cell culture, which remains the reference technique.

\section{MATERIALS AND METHODS}

\section{Residual Sludge}

Three types of sludge were sampled from two waste-water treatment plants in Lorraine, France. Primary sludge was taken from the primary decanting ponds of the Nancy and Metz treatment plants; activated sludge and thickened sludge from a secondary decanting pond were taken from the Metz plant. Samples of thickened sludge (78\% dry solids) loaded with $7 \times 10^{4}$ and $7 \times 10^{3}$ pfu poliovirus 1 vaccine (Sabin) were used as controls.

\section{Virus Extraction and Concentration Technique}

Virus was eluted from sludge samples using the technique described by Ahmed and Sorensen (1). A volume of sludge providing $10 \mathrm{~g}$ (dry solids), to which $100 \mathrm{~mL} 10 \%$ beef extract $(\mathrm{pH}$ 9.0) (Oxoid, Basingstoke, UK) had been added, was stirred at $500 \mathrm{rpm}$ for $30 \mathrm{~min}$. The mixture was sonicated on ice $(100 \mathrm{~W}, 0.9 \mathrm{~s})$ for $5 \mathrm{~min}$ in 1-min steps, mixed again for $5 \mathrm{~min}$ and then centrifuged at $5000 \times g$ for $1 \mathrm{~h}$ at $4^{\circ} \mathrm{C}$. The extract consisted of the supernatant, neutralized to $\mathrm{pH}$ 7.2. This extract was concentrated using polyethylene glycol (PEG) 6000 (Prolabo, Fontenay sous bois, France) and precipitated according to the Lewis and Metcalf technique (12). An $8 \%$ final concentration (w/v) PEG 6000 (in PBS, pH 7.2, bioMerieux, Lyon, France) was added to the extract. After vigorous agitation, the mixture was stored overnight at $4^{\circ} \mathrm{C}$ and then centrifuged at $10000 \times g$ for $90 \mathrm{~min}$ at $4{ }^{\circ} \mathrm{C}$. The pellet was resuspended in $10 \mathrm{~mL}$ PBS. Finally, this concentrate was decontaminated by adding a onethird volume of chloroform (10-min centrifugation at $1500 \times g$ ) followed by $200 \mu \mathrm{L}$ antibiotic cocktail (penicillin $100000 \mathrm{IU} / \mathrm{mL}$, colimycin $250000 \mathrm{IU} /$ $\mathrm{mL}$, streptomycin $100 \mathrm{mg} / \mathrm{mL}$ and amphotericin B $0.5 \mathrm{mg} / \mathrm{mL}$ ).

\section{Quantification of Infectious Enterovirus Using Cell Culture}

Quantities of the present infectious enterovirus were measured by inoculating the decontaminated concentrates in vitro into buffalo green monkey cell cultures in 96-well microplates. All cultures were inoculated in duplicate using 40 wells for each dilution (fivefold serial dilutions). Each well was filled with $50 \mu \mathrm{L}$ inoculum and $200-\mu \mathrm{L}$ nutritive medium [Eagle minimum essential medium (Eurobio, Les Ulis, France), to which 5\% newborn calf serum had been added] containing $1.5 \times 10^{5}$ cells $/ \mathrm{mL}$. The cultures were incubated at $37^{\circ} \mathrm{C}$ in $5 \%$ $\mathrm{CO}_{2}$ for five days. Virus density was 
determined from the cytopathic effects observed after duplicate inoculation of cell layers with three successive dilutions of the sample. The cytopathic effect was confirmed by two serial passages. The mean viral concentration for each sample was estimated using the most probable number (MPN) method with software devised by Maul (15). Results were expressed in the most probable number of colony unit (MPNCU)/mL sample and then converted to MPNCU/10 g sludge (dry solids) to take into account any variations in sludge dryness.

\section{Extraction of Viral RNA}

Enterovirus RNA was extracted from $250 \mu \mathrm{L}$ concentrate using the RNeasy ${ }^{\circledR}$ plant mini kit (Qiagen, Courtaboeuf, France) according to the manufacturer's instructions, with the following exception: the kit RLT buffer was modified by the addition of $2 \%$ (w/v) PVP 40000 (Sigma, St. Quentin, France) $(4,22,26)$.

\section{Fluorogenic RT-PCR}

To design the primers and probe for the TaqMan technology, the most constant genome region in enteroviruses, the $5^{\prime}$-noncoding region $\left(5^{\prime} \mathrm{NCR}\right)$, was chosen. The software Primer Express was used and identified primer Ev1 [5'-GATTGTCACCATAAGCAGC-3'] (position 579-597), primer Ev2 [5'-CCCCTGAATGCGGCTAATC-3'] (position 451-469) and Ev-probe [5'FAM-CGGAACCGACTACTTTGGGTGTCCGT-TAMRA-Phosphor-3'] (position 532-557). These primers were tested in the GenBank ${ }^{\circledR}$ database and found to be pan-specific and to cover all enteroviruses present in GenBank.

The reaction mixture (final volume $25 \mu \mathrm{L}$ ) was prepared in a single tube as follows: $1 \times$ TaqMan buffer A, $5.5 \mathrm{mM}$ $\mathrm{MgCl}_{2}$ (both from PE Biosystems, Courtaboeuf, France); $500 \mu \mathrm{M}$ dNTPs (Roche Molecular Biochemicals); 500 $\mathrm{nM}$ reverse primer Ev1, $400 \mathrm{nM}$ primer Ev2 (both from Genosys, Pampisford, UK); 120 nM Ev-probe (Eurogentec, Serraing, Belgium); 6\% glycerol (Prolabo); 1.7\% PVP-25 (Serva, Paris, France); $1.5 \mu \mathrm{g}$ T4 gene 32 protein (Amersham Pharmacia Biotech, Orsay,
France); 5 UI MuLV and 2.5 UI Ampli$\mathrm{Taq}^{\circledR}$ Gold (both from PE Biosystems) and 10 UI RNasin ${ }^{\circledR}$ (Promega, Charbonnière, France). Twenty microliters of the reaction mixture were added to the PCR tubes containing $5 \mu \mathrm{L}$ RNA from one of the sludge samples or RNA from the constructed standard in serial dilution. Enterovirus RNA was reverse transcribed into cDNA $\left(45 \mathrm{~min}\right.$ at $\left.50^{\circ} \mathrm{C}\right)$ and the 147-bp fragment was amplified by PCR $\left(45\right.$ cycles of $94^{\circ} \mathrm{C}$ for $15 \mathrm{~s}$ and $60^{\circ} \mathrm{C}$ for $1 \mathrm{~min}$ ) on an ABI Prism 7700.

\section{Enterovirus RNA Standard for Absolute Quantification}

An RNA standard representing the 5'NCR of enterovirus RNA was synthesized in vitro as follows: cDNA from 


\section{Short Technical Reports}

Mahoney type 1 poliovirus was amplified by PCR using primerEv1Clon 5'-TGGCCAATCGAATTCGCT TTA-3' (position 612-632) and primer Ev2Clon 5'-CTACATAAGGA TCCTCCGGCC-3' (position 432-452) modified by the introduction of restriction sites (Bam $\mathrm{HI}$ and $E c o$ RI). The 201-bp fragment was identified on a $1.5 \%$ agarose gel, excised, isolated from the gel and ligated into the polylinker of a pT7-blue vector (Novagen, Madison, WI, USA). The recombinant plasmid (pT7-EV) was transformed into $E$. coli (Novagen) and a positive colony was amplified in LB medium containing tetracycline and ampicillin. Plasmids were purified by alkaline lysis (2), linearized, purified by gel electrophoresis and extracted from the gel using a plasmid maxi kit (Qiagen).

Standard plasmids were quantified using spectrophotometric analysis. The sequence and orientation were verified by automatic sequencing. Linearized plasmid $(1.5 \mu \mathrm{g})$ was used to perform an in vitro transcription reaction with T7 DNA polymerase (Roche Molecular Biochemicals) at $37^{\circ} \mathrm{C}$ for $2 \mathrm{~h}$. After digestion with RNase-free DNase, the resulting RNA transcripts were purified with phenolchloroform and precipitated with isopropanol. The RNA transcripts were dissolved in sterile, RNase-free water and quantified by spectrofluorometric analysis using Ribogreen ${ }^{\circledR}$ (Interchim, Montluçon, France). The titer was $10^{10}$ copies $/ \mu$ L. Dilutions (five copies to $2 \times 10^{7}$ ) of the RNA standard were made in TE buffer containing RNasin. Aliquots of the diluted RNA stock were frozen immediately at $70^{\circ} \mathrm{C}$. Each aliquot was used once only for a fluorogenic RT-PCR.

\section{Analysis of Fluorescence Signals on the ABI Prism 7700}

Real-time fluorescence measurements were taken and the threshold cycle $\left(C_{t}\right)$ value for each sample was calculated by determining the point at which fluorescence exceeded a threshold limit (10 times the baseline SD). A standard graph of the $C_{t}$ values obtained from the serially diluted external RNA standard was compiled. The correlation coefficient and the slope were calculated. $\mathrm{C}_{\mathrm{t}}$ values from the sludge samples were plotted on the standard curve, and the number of copies was calculated automatically by Sequence Detector v1.6. Samples were defined as negative if their $C_{t}$ values exceeded 45 cycles.

\section{RESULTS AND DISCUSSION}

During the development of this method, the optimal conditions for RTPCR were determined by amplifying a range of the standard RNA. A problem we encountered was that of sensitivity
(Figure 1A; detection limit $=1.6 \times 10^{4}$ copies) related to the secondary structures present in the $5^{\prime} \mathrm{NCR}$ of the enterovirus genome. For this reason, we decreased the RT/Taq ratio and used the $\mathrm{T} 4$ gene 32 protein, usually considered to be a ssDNA binding protein and a dsDNA helicase $(11,3)$. Figure 1B demonstrates the benefits of adding this protein to the reaction mixture (in quantities of $1.5 \mu \mathrm{g} /$ reaction) on the amplification yield of the standard RNA.

The detection limit, intra-assay and

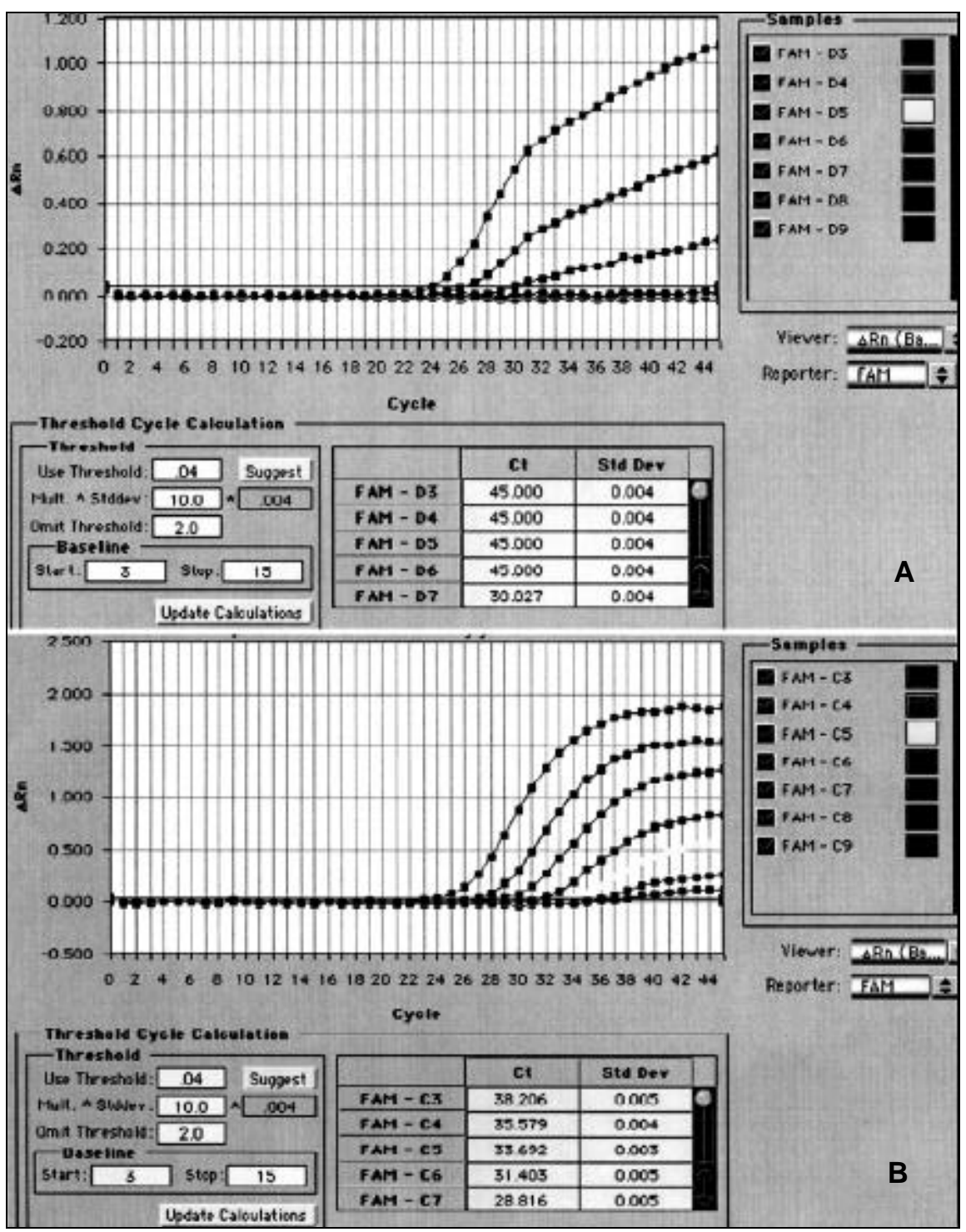

Figure 1. Comparison of intensity and amplification quality in sludge extracts. These extracts contains seven successive fivefold dilutions of standard RNA ( 25 to $4 \times 10^{5}$ copies) in the presence and absence of T4 gene 32 protein (Fam C3-D3 = 25, Fam C4-D4 = 125, Fam C5-D5 = 640, Fam C6-D6 = 3.2 $\times 10^{3}$, Fam C7-D7 $=1.6 \times 10^{4}$, Fam C8-D8 $=8 \times 10^{4}$, Fam C9-D9 $\left.=4 \times 10^{5}\right)$. 1A: Amplification in the absence of T4 gene 32 protein, three dilutions are amplified. 1B: Amplification in the presence of T4 gene 32 protein, all dilutions are amplified. 
Table 1: Enterovirus Quantification Measurements.

\begin{tabular}{|c|c|c|}
\hline Samples & $\begin{array}{l}\text { from RT-PCR } \\
\text { pies/10 g dry solids) }\end{array}$ & $\begin{array}{l}\text { Results from cell culture } \\
\text { (MPNCU/10 g dry solids) }\end{array}$ \\
\hline control $1\left(7 \times 10^{4} \mathrm{pfu}\right)$ & $1.5 \times 10^{6}$ & $4.9 \times 10^{4}$ \\
\hline control $2\left(7 \times 10^{4} \mathrm{pfu}\right)$ & $1.4 \times 10^{6}$ & $3.5 \times 10^{4}$ \\
\hline control $3\left(7 \times 10^{4} \mathrm{pfu}\right)$ & $8 \times 10^{6}$ & $3.4 \times 10^{4}$ \\
\hline control $4\left(7 \times 10^{4} \mathrm{pfu}\right)$ & $1 \times 10^{6}$ & $1.4 \times 10^{4}$ \\
\hline control $5\left(7 \times 10^{4} \mathrm{pfu}\right)$ & $7 \times 10^{6}$ & $2.2 \times 10^{4}$ \\
\hline control $6\left(7 \times 10^{3} \mathrm{pfu}\right)$ & $2 \times 10^{5}$ & $1.6 \times 10^{3}$ \\
\hline control $7\left(7 \times 10^{3} \mathrm{pfu}\right)$ & $3 \times 10^{5}$ & $3.6 \times 10^{3}$ \\
\hline control $8\left(7 \times 10^{3} \mathrm{pfu}\right)$ & $1 \times 10^{5}$ & $1.7 \times 10^{3}$ \\
\hline $1 \mathrm{P}$ & 54720 & 10 \\
\hline $2 \mathrm{P}$ & 230400 & 2242 \\
\hline $3 P$ & 115200 & 326 \\
\hline $4 \mathrm{~A}$ & 5664 & 107 \\
\hline $5 A$ & 14400 & 278 \\
\hline $6 \mathrm{~A}$ & $<400$ & $<3$ \\
\hline $7 \mathrm{~T}$ & 14400 & $<3$ \\
\hline $8 \mathrm{~T}$ & 14400 & 72 \\
\hline 9T & $<400$ & $<3$ \\
\hline \multicolumn{3}{|c|}{$\begin{array}{l}\text { Measurements use RT-PCR and cell culture in eight sludge samples artificially } \\
\text { contaminated with } 7 \times 10^{4} \text { and } 7 \times 10^{3} \text { pfu poliovirus } 1 \text { and nine natural sludge } \\
\text { samples of three different types }(P=\text { primary, } A=\text { activated, } T=\text { thickened). }\end{array}$} \\
\hline
\end{tabular}

interassay variability were determined in 10 replicates of tenfold dilution standards, from 5 to $5 \times 10^{6}$ RNA copies, amplified in eight independent assays. Intra-assay CVs varied between $6.34 \%$ and $0.74 \%$, and interassay CVs between $4.51 \%$ and $0.66 \%$. The values of $6.34 \%$ and $4.51 \%$ obtained with low RNA concentrations agree with those found in other TaqMan reactions $(3.4 \%$ and $6.2 \%)(6,14)$. A variability of five copies of the standard is acceptable, and no negative result was obtained. The sensitivity of the RT-PCR is therefore five copies.

Other problems encountered were those caused by the complexity of the material, such as the residual sludge. Sludges contain numerous inorganic and organic compounds-humic acids and polyphenols, for example-which are liable to form complexes with nucleic acids and inhibit amplification enzymes. Figure 2 shows the presence of such inhibitor substances on the graphs fam-D1 produced by the Sequence Detector software when $8 \times 10^{4}$ copies of enterovirus RNA from a sludge sample were amplified. PVP is described in the literature as forming complexes with phenolic compounds $(9,26)$. For maximum effect, it was added both at the RNA extraction stage and to the PCR mixture (Figure 2, Fam-D6). The amount of PVP required in the RNA extraction process was fixed at $2 \%$ as in the cetyltrimethylammonium bromide (CTAB) extraction protocol (22), while the amount required in the amplification mixture was determined by adding various quantities between $1 \%$ and $2 \%$, as did Koonjul et al. (9). The optimum PVP amount was found to be $1.7 \%$.

The analytical sensitivity of our method, considering all extraction steps, is 2000 copies/10 $g$ (dry solids) of sludge. However, lower numbers can be found because the linearity of the standard curve permits the interpolation of values below the lower limit of the dynamic range (14). Therefore, the theoretical detection limit of our RT-PCR can be adjusted to 400 copies/10 g (dry solids). This sensitivity is compatible with requirements accepted in the liter- 


\section{Short Technical Reports}

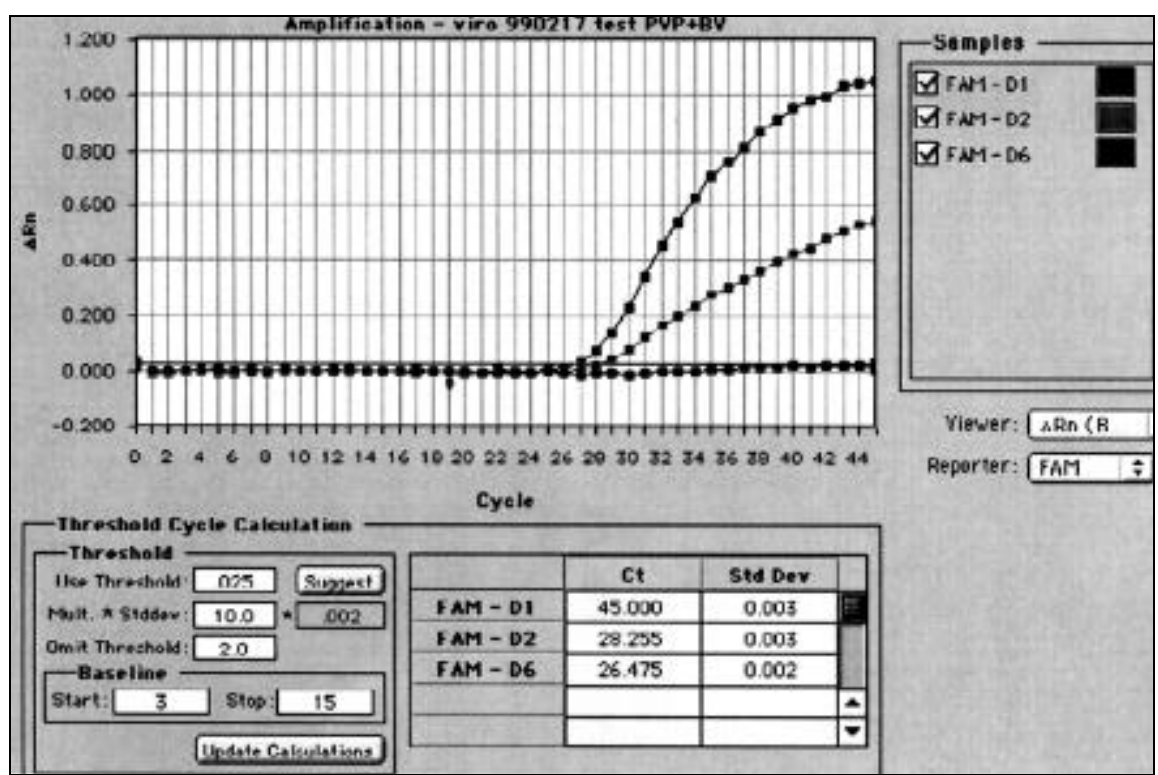

Figure 2. Graph showing fluorescence intensity as a function of numbers of amplification cycles. Comparison of amplification intensity of the same sludge concentrate $(10 \mu \mathrm{L})$ containing $8 \times 10^{4}$ copies of RNA under different reaction conditions. Fam-D1: RNA extraction and amplification without PVP; Fam-D2: RNA extraction with PVP, amplification without PVP; Fam-D6: RNA extraction and amplification with PVP.

ature as suitable for the detection of enteroviruses in sludge from waste-water treatment plants $(10,20,23,24)$.

This fluorogenic RT-PCR protocol was first evaluated on eight samples of artificially contaminated thickened sludge and then applied to nine natural sludge samples. The results, presented in Table 1, were compared to measurements made of virus quantities by means of cell culture. For the samples artificially contaminated with $7 \times 10^{4}$ or $7 \times 10^{3} \mathrm{pfu}$, the mean values as measured by RT-PCR and cell culture, respectively were $3.78 \times 10^{6}$ copies $/ 10 \mathrm{~g}$ and $3.08 \times 10^{4} \mathrm{MPNCU} / 10 \mathrm{~g}(\mathrm{n}=5)$ or $2 \times 10^{5}$ copies $/ 10 \mathrm{~g}$ and $2.96 \times 10^{3} \mathrm{MP}$ NCU/10 g $(n=3)$ (Table 1). In the natural sludge samples, two samples were negative $(<400$ copies/10 g) according to RT-PCR and three according to cell culture (<3 MPNCU).

The quantity of genomic RNA measured was always larger than the number of infectious particles, being on average 150 times greater for natural sludge and 120 times greater for contaminated sludge. This can be explained by (i) the aggregation of infectious particles into clumps that, while consisting of several viruses, only cause one area of lysis in a cell culture; (ii) the variable effects of cell culture inhibitory substances that might still be present in the concentrates; and (iii) the ability of RTPCR to detect inactivated viruses. These results, which agree with those reported in the literature $(8,18,19)$, show a sharp decrease in quantities of virus present from primary sludge through activated and thickened sludges.

The fluorogenic RT-PCR technique developed in this study allows real-time analysis of the amplification reaction and calculation of genomic RNA quantities at the start of the exponential phase of amplification. The fluorescence signal caused by cleavage of the TaqMan fluorogenic probe can only be generated if the target sequence has been amplified, which gives the reaction a high level of specificity. Our protocol is sensitive, reproducible and rapidly executed on multiple samples. These features make it an excellent large-scale screening tool for sludge from waste-water treatment plants and for monitoring sewage processing procedures, even though the presence of infectious particles must be confirmed by cell culture, as current regulations require.

\section{REFERENCES}

1.Ahmed, A.U. and D.L. Sorensen. 1995. Kinetics of pathogen destruction during storage of dewatered biosolids. Wat. Environ. Res. 67:143-50.
2.Birnboim, H.C. and J. Doly. 1979. A rapid alkaline extraction procedure for screening recombinant plasmid DNA. Nucleic Acids Res. 7:1513-1523.

3.Chandler, D.P., C.A. Wagnon and H. Bolton, Jr. 1998. Reverse transcriptase (RT) inhibition of PCR at low concentrations of template and its implications for quantitative RT- PCR. Appl. Environ. Microbiol. 64:669-677.

4.Felske, A., B. Engelen, U. Nübel, and H. Backhaus. 1996. Direct ribosome isolation from soil to extract bacterial rRNA for community analysis. Appl. Environ. Microbiol. 62:4162-4167.

5.Gibson, U.E., C.A. Heid and P.M. Williams. 1996. A novel method for real time quantitative RT-PCR. Genome Res. 6:995-1001.

6.Gut, M., C.M. Leutenegger, J.B. Huder, N.C. Pedersen and H. Lutz. 1999. One-tube fluorogenic reverse transcription-polymerase chain reaction for the quantitation of feline coronaviruses. J. Virol. Methods 77:37-46.

7.Higuchi, R. 1992. Simple and rapid preparation of samples for PCR, p. 31-38. In H.A. Erlich (Ed.), PCR Technology. W.H. Freeman and Co., New York.

8.Hu, C.J., R.A. Gibbs, G.E. Ho, P. Phillips and I. Unkovich. 1995. Pathogen densities in waste water sludge treated by anaerobic digestion and dewatering. 3rd International Conference Appropriate Waste Management Technologies for Developing Countries.

9.Koonjul, P.K., W.F. Brandt, J.M. Farrant and G.G. Lindsey. 1999. Inclusion of polyvinylpyrrolidone in the polymerase chain reaction reverses the inhibitory effects of polyphenolic contamination of RNA. Nucleic Acids Res. 27:915-916.

10.Kopecka, H., S. Dubrou, J. Prevot, J. Marechal and P.J.M. Lopez. 1993. Detection of naturally occurring enteroviruses in waters by reverse transcription, polymerase chain reaction, and hybridization. Appl. Environ. Microbiol. 59:1213-1219.

11.Kreader, C.A. 1996. Relief of amplification inhibition in PCR with bovine serum albumin or T4 gene 32 protein. Appl. Environ. Microbiol. 62:1102-1106.

12.Lewis, G.D. and T.G. Metcalf. 1988. Polyethylene glycol precipitation for recovery of pathogenic viruses including hepatitis A and human rotavirus from oyster, water and sediments. Appl. Environ. Microbiol. 54:1983-1988.

13.Livak, K.J., S.J. Flood, J. Marmaro, W. Giusti and K. Deetz. 1995. Oligonucleotides with fluorescent dyes at opposite ends provided a quenched probe system useful for detecting PCR product and nucleic acid hybridization. PCR Methods Appl. 4:357-362.

14.Martell, M., J. Gomez, J.I. Esteban, S. Sauleda, J. Quer, B. Cabot, R. Esteban and J. Guardia. 1999. High-throughput real-time reverse transcription-PCR quantitation of hepatitis C virus RNA. J. Clin. Microbiol. 37:327332.

15.Maul, A. 1991. Aspects statistiques des methodes de quantification en virologie, p. 143-171. In Lavoisier (Ed.), Virologie des milieux hydriques. Schwartzbrod Tec. \& Doc., Paris.

16.Metcalf, T.G., J.L. Melnick and M.K. Estes. 1995. Environmental virology: from detection of virus in sewage and water by isolation to identification by molecular biology—a trip of 
over 50 years. Annu. Rev. Microbiol. 49:461487.

17.Muller-Wegener, U. 1988. Interaction of humic substances with biota, p. 179-192. In F.H.

Frimmel and R.F. Christman (Eds.), Humic Substances and Their Role in the Environment. John Wiley \& Sons, Inc., New York.

18.Pederson, D. 1981. Density levels of pathogenic microorganisms in municipal waste water sludge: indicator organism in sonoran desert soil amended with sewage sludge. J. Environ. Sci. Health A28:1287-1302.

19.Soares, A.C., T.M. Straub, I.L. Pepper and C.P. Gerba. 1994. Effect of anaerobic digestion on the occurrence of enteroviruses and Giardia cysts in sewage sludge. J. Environ. Sci. Health A29:1887-1897.

20.Sobsey, M.D. 1994. Molecular methods to detect viruses in environmental samples., pp. 387400. In R.C. Spencer, E.P. Wright and S.W.B. Newsom (Eds.), Rapid Methods and Automation in Microbiology and Immunology. Intercept Ltd., Andover, Hampshire, UK.

21.Staub, U., H. Polivka and H.J. Gross. 1995. Two rapid microscale procedures for isolation of total RNA from leaves rich in polyphenols and polysaccharides : application for sensitive detection of grapevine viroids. J. Virol. Methods 52:209-218.
22.Stewart, N.C., Jr. and L.E. Via. 1993. A rapid CTAB DNA isolation technique useful for RAPD fingerprinting and other PCR application. BioTechniques 14:748-749.

23.Straub, T.M., I.L. Pepper and C.P. Gerba. 1994. Detection of naturally occurring enteroviruses and hepatitis A virus in undigested and anaerobically digested sludge using the polymerase chain reaction. Can. J. Microbiol. 40:884-888.

24.Straub, T.M., I.L. Pepper, M. Abbaszadegan and C.P. Gerba. 1994. A method to detect enteroviruses in sewage sludge-amended soil using the PCR. Appl. Environ. Microbiol. 60:1014-1017.

25.Tsai, Y.-L. and S.L. Parker. 1998. Quantification of poliovirus in seawater and sewage by competitive reverse transcriptase polymerase chain reaction. Can. J. Microbiol. 44:35-41.

26.Wan, C.-Y. and T.A. Wilkins. 1994. A modified hot borate method significantly enhances the yield of high-quality RNA from cotton. Anal. Biochem. 223:7-12.

This study is based on work supported by A.d.e.m.e (the French environment and energy management agency) and Anjou Recherche. We thank INSERM U437 and Perkin
Elmer for technical support with the ABI Prism 7700. Address correspondence to Dr. Serge Monpoeho, Laboratoire de Virologie CHU Hotel Dieu, 9 quai moncousu, 44035 Nantes, France. e-mail: sbillaudel@chunantes.fr

Received 23 July 1999; accepted 15 March 2000.

S. Monpoeho, A. Dehée 2 , B. Mignotte, L. Schwartzbrod ${ }^{1}$, V. Marechal' ${ }^{2}$,J.-C. Nicolas ${ }^{2}$, S. Billaudel and V. Férré Laboratoire de Virologie $\mathrm{CHU}$ de Nantes, Nantes

${ }^{1}$ Laboratoire de Virologie faculte de pharmacie Nancy, Nancy

${ }^{2}$ Laboratoire de Virologie hopital Rothschild

Paris, France 